\section{EU CRISES MULTIPLIER - FROM ONE CRISIS TO ANOTHER}

\author{
Ivana V. Pešić \\ Eurobank JSC Belgrade, Serbia \\ $\triangle$ pesic.ivana@gmail.com,Ivana.Pesic3@eurobank.rs
}

Gajo M. Vanka

Wageningen University and Research Centre, Wageningen School of Social Sciences (WASS)

\gvanka@leomail.tamuc.edu,vankagajo@yahoo.co.uk,gajo.vanka@telenor.rs

UDC

339.932:061.1

EU:338.124.4

Review paper

Received:

25.02.2014

Accepted: 10.06.2014
Apstrakt: Since the wide spreading of the European Union (EU) crisis begun, the research papers have been providing different definitions such as currency crisis, competitiveness crisis, banking crisis, balance of payment crisis, but the most frequent notion of EU crises is the sovereign debt crisis. In this paper, the researchers agree that the current European crisis can be identified as sovereign debt crises at its surface, but in order to search for solutions of EU problems, we must look deeper into the sources of this crisis. Through this paper, the multiplication of crisis is explained, whereby it is being concluded that one type of crisis led to another, while staying on the point that the Eurozone current crisis is basically a combination of two core crisis: balance of payment crisis and banking crisis. In order to support the hypothesis that sovereign debt crisis is deeply connected with balance of payment crisis, we have analysed the trade and capital flows of European countries. It was discovered that periphery countries mostly financed their current account deficit, trade deficits and public deficit through external borrowing from creditor countries. Further, the periphery countries have been cumulating not only trade deficit in trade activity with other European partners, but also in trade with the rest of the world. The key source of imbalances between the European countries seems to be a different level of competitiveness caused by different level of productivity. As the second face of EU crises, we recognised a banking crisis. We found that sovereign debt crisis and banking crisis are interconnected but banking crisis usually precedes the debt crisis. With the fast growth of international capital flows, financial integration was strongly regionally concentrated and became especially important within the EU. Through the analysis of the international investment position of creditor countries, it was concluded that these countries are more integrated within the euro area through financial flows than through real economic flows. Additionally, it was discovered that creditor countries' banks were among the biggest investors in bonds of periphery countries such as Greece. In other periphery countries such as Ireland, banking crisis and subsequent measures for the rescuing of banking system led to the increase of public debt. In the other countries, banks were faced with solvency problems due to bad debt holdings. Having in mind that we found interconnection of the debt crisis with balance of payment crisis on the one side, and with the banking crisis on the other side, the conclusion is that sovereign debt crisis in the Eurozone is a result of two-core crisis: balance of payment crisis and bank crisis. Reckoning on the European Union history where each crisis usually led to the stronger integration, maybe the current crisis is a step further towards better and deeper integration.

Key words: balance-of-payments crisis, banking crisis, competitiveness, productivity, intra-trade, sovereign debt crisis, PIIGS. 


\section{Introduction}

European crisis usually recognised as a sovereign debt crisis started with evidence that some members of the European Union became unable to service further their external financial obligations. When it became obvious that growing external debt is not sustainable anymore, the markets put additional pressure, which resulted in an increase of prices for additional borrowing. Once the debt crisis occurred and seriously hit the European Union as a whole, it became evident that there had to be some deeper causes and issues to be resolved. The European crisis challenged not only European and national authorities, but also academics, analysts and practitioners. Some academic works deserve to be mentioned here in order to show how many complexities the Eurozone crisis incorporates.

According to Featherstone (2011), the Greek crisis that erupted in the autumn of 2009 created unprecedented challenges to both the governance of the 'euro area' and of Greece that risked a conflagration on the international financial markets and received worldwide attention.

Having in mind strong interconnection between the members' countries, the crisis spillover through the European Union was inevitable putting the Union in the state of the most serious crisis since its creation. The officials have recognised that excluding the crisis countries from the common currency union could lead to enormous costs. Hereafter, they came to the agreement that rescue of countries with debt problem is a necessary action in order to prevent the collapse of the European Union as a whole. The first set of financial assistance package from the EU and the IMF has been provided to Greece in May 2010 in order to avoid default. However, the investors also became nervous about Ireland and Portugal, which immediately influenced increase of the bond, spreads. After Greece, Ireland and Portugal also requested financial assistance. A set of policy measures was aimed to calm down the market pressure and contagion particularly in Italy and Spain who have been seen as the next countries with potential debt problem. Even the short-term measures brought some positive results, the EU is still seen as vulnerable, and long-term survival of a common currency is still questioned.

Searching for the causes of the European crisis, De Grauwe (2011) has identified three actors who played a role in the development of the crisis: Greece, the financial markets, and the Eurozone authorities.

As official statistic showed, the countries affected by the crisis did not respect the common rules in the years before the crisis. Rane (2012) reminds us that the original design of euro sought to address the over-borrowing incentive problems in two ways; firstly, the Stability and Growth Pact set limits on the size of the annual budget deficit is $3 \%$ of GDP and the stock of public debt of 
$60 \%$ of GDP. Secondly, the rules included a "no bailout" clause with the implication that a sovereign default would occur if a national government failed to meet its debt obligations.

Todorovic and Bogdanovic (2011) provide a comprehensive presentation of different factors that have caused the debt crises in Greece and Ireland. They pointed out that the crisis in Greece has occurred as a consequence of the large borrowing in international capital markets to finance the budget deficit and current account deficits while Ireland debt crises was primarily caused by bank crisis. Further, debt crisis in the EU discovered once again that the model of economic growth based on the financing of consumption through borrowing in the long term does not give positive results (Todorovic and Bogdanovic 2011).

Muyer (2011) explaines that below the surface of the euro area's public debt and banking crisis lies a balance of payment crisis caused by a misalignment of internal real exchange rates.

Sinn (2012) initiates significant academic debate in relation to European imbalances in inter-bank payment system TARGET 2. Sinn (2012) asserts that TARGET 2 contributed to the maintenance of current account deficits of peripheral countries.

Blundell-Wignall and Slovik (2011) explore the European crisis issues from a market perspective indicating that Europe was hit by the interrelated banking crisis and sovereign debt crisis.

The European Central Bank has presented an interesting point of view regarding the transmission of the crisis. A significant channel for the transmission of shocks was built by trade integration within the euro that has increased continuously during the previous years. In the years leading up to the global financial crisis, euro area countries with large current account deficits typically also recorded large trade deficits vis-à-vis the rest of the euro area. (ECB Monthly bulletin 2013).

Bibow (2012) determines the European crisis as twin crises - balance of payment and banking crisis indicating that policy prescriptions for the "sovereign debt crisis" have been derived from misdiagnosis and will make the situation worse. According to Bibow (2012), Germany reneged on the golden rule of a monetary union: commitment to a common inflation rate, and this country largely contributed to the building of European imbalances. Germany is faced with a dilemma/trilemma of its own making and must make a critical choice, since it cannot have it all - perpetual export surpluses, a no transfer / no bailout monetary union, and a "clean," independent central bank (Bibow 2012). 


\section{Material and Methods}

The complexity of the Eurozone crisis is presented by one comprehensive view of Mongelli (2013) who explains that crisis combines the features of a financial crisis in some countries with those of a balance-of-payment crisis or sluggish growth in another overlapping group of countries. All these factors have struck Europe before, but never all at the same time, in so many countries sharing a currency, and with limited adjustment mechanisms (Mongelli 2013).

In our view, the nature of the Eurozone crisis cannot be simply explained by theories of crises having in mind several facts. Firstly, the crises in different European countries seem to have different causes. Secondly, even though some theories of crises can be applied to one country, some of them are not applicable on monetary union as a whole. Third, the EU crisis contains different crises in its core and has mutated from one form of crisis to another. However, there are several common points of European crisis with the theory:

- Permanent financing of the current account deficit and budget deficit by external borrowing is unsustainable at long term;

- Trade and capital linkages are the most significant channels for crisis transmission between the countries;

- Liberalisation of capital flows without adequate regulation encourages financial crisis;

- Beside fundamentals, financial market panic can put additional pressure on crisis area.

In this research we present several aspects of the European crisis by using a wide set of official statistical data published by Eurostat statistics, the Bank of International Settlements statistics, and statistics of national central banks of European Union members. The members of the European Union are strongly connected through trade and capital flows so we have investigated both of them. The countries that are in the primary focus of our research are split in two groups. The first group is composed of the so-called PIIGS countries that we named as "periphery countries": Portugal, Ireland, Italy, Greece, and Spain. The second group that we named as "creditor countries" refers to the members of the European Union that are supposed to be the biggest creditors having the most significant exposure towards "periphery countries" debt. The scope of works covers the data for the last decade.

The research starts with an investigation of the current account, trade account, and net investment position of mentioned group of countries in order to test the hypothesis that the crisis countries financed its current account and trade account deficit by external borrowings. Further, we split the trade balance between the balance of trade with third countries and balance of intra-EU trade having in mind that intra-EU trade represents more than $60 \%$ of total EU trade. 
It is likely that either first or second trade balance has more significant importance in building the current account balance. It could be also possible that external borrowing is used in financing external trade deficit or intraregional trade deficit. The biggest part of this research is devoted to intraEuropean imbalances.

In the next part, we have investigated the net investment position of creditor countries. Particular attention is given to the structure of creditor countries' investments abroad in order to test the hypothesis that creditor countries more invested in financial assets than through foreign direct investment (FDI).

In order to show that capital flows played significant role in the integration between the countries, we also analyse the statistics of BIS regarding biggest holders of periphery countries' debt.

Finally, we put additional attention on financial market's reaction especially regarding bonds of periphery countries. The aim was to find the interconnection between the banking crisis and sovereign debt crisis.

The final objective of this research was to show the existence of a phenomenon that we called "crisis multiplier" which can be the subject of some future research.

\section{Internal Imbalances: Current Account Balance, Trade Balance and Net Investment Position}

In the years before the global economic crisis of 2007, it had been obvious that some EU countries had continuously recorded current account deficits, budget deficits, and high government debt. On the other side, some of EU members had had an inverse flow of mentioned indicators showing that there existed significant internal imbalances within the EU.

As De Grauwe (2012) explaines, one of the major problems of the Eurozone is a divergence of the competitive positions that have built up since the early 2000s. This divergence has led to major imbalances in the Eurozone where the countries that have seen their competitive positions deteriorate (mainly the "PIIGS") have accumulated large current account deficits and thus external indebtedness, matched by current account surpluses of the countries such as Germany that have improved their competitive positions (De Grauwe 2012).

As shown in following Table 1, PIIGS countries recorded a persistent increase of current account deficit until 2007 while creditor countries recorded a persistent increase of current account surplus (except for France). 
Table 1 Current Account Balance in Percentage of GDP - Three-Year Average

\begin{tabular}{|c|c|c|c|c|c|c|c|c|c|c|}
\hline \multicolumn{11}{|c|}{ PIIGS } \\
\hline & 2003 & 2004 & 2005 & 2006 & 2007 & 2008 & 2009 & 2010 & 2011 & 2012 \\
\hline Ireland & -0.5 & -0.5 & -1.4 & -2.5 & -4.1 & -4.8 & -4.4 & -2.3 & 0 & 2.4 \\
\hline Greece & -6.8 & -6.3 & -6.7 & -8.3 & -11.2 & -13.6 & -13.6 & -12.1 & -10.4 & -7.7 \\
\hline Spain & -3.6 & -4 & -5.4 & -7.2 & -8.8 & -9.5 & -8.1 & -6.3 & -4.3 & -3.1 \\
\hline Italy & -0.3 & -0.5 & $\begin{array}{l}-0.7 \\
\end{array}$ & -0.9 & -1.2 & -1.9 & -2 & -2.8 & -2.9 & -2.4 \\
\hline Portugal & -8.3 & -7.7 & -8.4 & -9.8 & -10.4 & -11.1 & -11.2 & -11.4 & -9.5 & -6.4 \\
\hline \multicolumn{11}{|c|}{ CREDITORS } \\
\hline Germany & 1.3 & 2.9 & 3.9 & 5.3 & 6.3 & 6.6 & 6.5 & 6.1 & 6.1 & 6.5 \\
\hline France & 1.1 & 0.7 & 0.2 & -0.2 & -0.7 & -1.1 & -1.4 & -1.5 & -1.6 & -1.9 \\
\hline Netherlands & 3.6 & 5.3 & 6.9 & 8.1 & 7.8 & 6.8 & 5.4 & 5.8 & 7.7 & 9.4 \\
\hline
\end{tabular}

Source: Eurostat statistics database

Even current account balance also includes net earnings from rents, interest, profits, dividends, and net transfer payments (such as pension funds and worker remittances), we suppose that the trade balance is the major contributor to the current account balance.

Table 2 Trade Balance Percentage of GDP - Three-Year average

\begin{tabular}{|c|c|c|c|c|c|c|c|c|c|c|}
\hline \multicolumn{11}{|c|}{ PIIGS } \\
\hline & 2003 & 2004 & 2005 & 2006 & 2007 & 2008 & 2009 & 2010 & 2011 & 2012 \\
\hline Ireland & 23.2 & 20.9 & 17.3 & 14.1 & 10.5 & 13.3 & 20.1 & 22.8 & 22.7 & 22.2 \\
\hline Greece & \begin{tabular}{|l|}
-13.1 \\
\end{tabular} & \begin{tabular}{|l|}
-13.7 \\
\end{tabular} & -14.3 & \begin{tabular}{ll|}
-16.9 \\
\end{tabular} & -18.6 & -18.9 & -13.3 & -12.7 & -13.1 & -10.1 \\
\hline Spain & -5.1 & -6.4 & -7.5 & -8.4 & -8.7 & -7.9 & -4 & -4.6 & -4 & -2.5 \\
\hline Italy & 0.7 & 0.6 & 0 & -0.7 & 0.2 & -0.1 & 0.1 & -1.3 & -1.1 & 1.1 \\
\hline Portugal & \begin{tabular}{ll|}
-9.4 \\
\end{tabular} & -10.9 & $\begin{array}{l}-11.8 \\
\end{array}$ & -11.4 & \begin{tabular}{|l|}
-11.3 \\
\end{tabular} & $\begin{array}{l}-13.4 \\
\end{array}$ & $\begin{array}{l}-10.6 \\
\end{array}$ & -11.1 & -8.3 & -5.2 \\
\hline \multicolumn{11}{|c|}{ CREDITOR COUNTRIES } \\
\hline Germany & 6 & 6.9 & 7 & 6.9 & 8.2 & 7.3 & 5.5 & 6.3 & 5.9 & 6.7 \\
\hline France & 0.2 & -0.2 & -1.3 & -1.7 & -2.2 & -3.1 & -2.3 & -2.7 & -3.7 & -3.5 \\
\hline Netherlands & 6.8 & 6.8 & 7.6 & 7.4 & 7.3 & 7 & 6 & 7.2 & 7.8 & 8.2 \\
\hline
\end{tabular}

Source: Eurostat statistics database

From the above data, it is evident that Greece, Spain, and Ireland had had a negative trend of the trade balance in the years before the crisis (Table 2). Greece and Spain increased its trade deficit while Ireland decreased its trade surplus. Italy also recorded negative trend of trade balance passing from trade surplus to trade deficit country in 2006. Ireland is the only country between the PIIGS who recorded a permanent trade surplus.

On the other side, trade performance of Germany has continuously improved while France and the Netherlands have had a different trend of trade balance. France has worsened its trade position, which is reflected in continuous increase of trade deficit while Netherlands trade surplus started to decrease in 2006.

Let us focus on current account balance and trade balance. Generally, the biggest part of current account balance represents trade balance. The trade deficit in the context of external financing through borrowing is observed as a whole. However, in order to explain the true existence of trade imbalances within the EU, it is necessary to split the trade balance between intra-regional 
trade balance and external trade balance or balance of trade with countries outside the EU. This is important because intra-EU trade deficit can be covered by surplus from trade with third countries and vice versa. It is possible that either external trade balance or intra-regional trade balance has more significant importance in building the current account balance. So, external borrowings could be used in either financing deficit of trade with countries outside the EU or financing intra-regional trade deficit.

From 2004 to 2008, Greek trade deficit was increasing at an average rate of $10.7 \%$, but increase of external trade deficit was stronger (12.9\%) than increase of intra-EU trade deficit (9.2\%). Spain was following the same trend as Greece. The average five-year growth rate was $16.2 \%$. The deficit in trade with third countries increased at a rate of $21.8 \%$ while intra-EU trade deficit increased at an average rate of $10.6 \%$. The same situation was present in Portugal which also followed an increase of the total trade deficit at a five-year average rate of $13.6 \%$. The growth rate for the external trade deficit was $14.7 \%$ while the average growth rate for intra-regional trade deficit was $13.5 \%$. Italy has the same trend as previously mentioned countries and it has even recorded a surplus in intra-EU trade. Mentioned trends led us to conclude that during the observed period Greece, Spain and Portugal have simultaneously worsened its intra-EU trade balance as well as the external trade balance, which indicates loss of their competitiveness.

Among the PIIGS countries, Ireland is the only country with a continuous trade surplus in the years before the crisis. However, even its surplus from trade with countries outside the EU was less or more stable, intra-regional trade surplus showed a negative trend during the observed period. Therefore, 5-year average rate of trade surplus decrease was $3.6 \%$. The surplus in trade with countries outside EU has been growing at rate 2.3\%, while intra-EU trade surplus shows a negative trend and has decreased at an average rate of 7.9\%.

PIIGS countries not only have been recorded negative current account balance and trade balance, but they also have increased their budget deficit and external borrowings during the observed period.

Table 3 Budget Deficit in Percentage of GDP

\begin{tabular}{|l|c|c|c|c|c|c|c|c|c|c|}
\hline \multicolumn{10}{|c|}{ PIIGS } \\
\hline & 2003 & 2004 & 2005 & 2006 & 2007 & 2008 & 2009 & 2010 & 2011 & 2012 \\
\hline Ireland & 0.4 & 1.4 & 1.7 & 2.9 & 0.1 & -7.4 & -13.9 & -30.8 & -13.4 & -7.6 \\
\hline Greece & -5.6 & -7.5 & -5.2 & -5.7 & -6.5 & -9.8 & -15.6 & -10.7 & -9.5 & -10 \\
\hline Spain & -0.3 & -0.1 & 1.3 & 2.4 & 1.9 & -4.5 & -11.2 & -9.7 & -9.4 & -10.6 \\
\hline Italy & -3.6 & -3.5 & -4.4 & -3.4 & -1.6 & -2.7 & -5.5 & -4.5 & -3.8 & -3 \\
\hline Portugal & -3.7 & -4 & -6.5 & -4.6 & -3.1 & -3.6 & -10.2 & -9.8 & -4.4 & -6.4 \\
\hline \multicolumn{8}{|c|}{ CREDITORS } & & & \\
\hline Germany & -4.2 & -3.8 & -3.3 & -1.6 & 0.2 & -0.1 & -3.1 & -4.1 & -0.8 & 0.2 \\
\hline France & -4.1 & -3.6 & -2.9 & -2.3 & -2.7 & -3.3 & -7.5 & -7.1 & -5.3 & -4.8 \\
\hline Netherlands & -3.1 & -1.7 & -0.3 & 0.5 & 0.2 & 0.5 & -5.6 & -5.1 & -4.5 & -4.1 \\
\hline
\end{tabular}

Source: Eurostat statistics database 
The data presented confirm that, between the PIIGS countries, Greece had been the absolute leader in budget deficit before the crisis (Table 3). The situation was equally bad in Portugal and Italy while Spain even recorded a budget surplus in 2005 and 2006. Ireland is the only country with a continuous budget surplus in the years before the crisis. On the side of creditor countries, we also see that Germany and France have a negative balance but it has a positive trend.

High trade deficit combined with significant budget deficit have reflected a several problems of the real Greek economy and inefficiently managed government budget that finally resulted in the debt crisis. These negative trends are combined with record government debt as presented in the following table (Table 4). Italy seems to be in the bad situation as well while Ireland is the country with the lowest government debt between the PIIGS countries.

Table 4 Gross Government Debt in Percentage of GDP

\begin{tabular}{|l|c|c|c|c|c|c|c|c|c|c|}
\hline \multicolumn{10}{|c|}{ PIIGS } \\
\hline & 2003 & 2004 & 2005 & 2006 & 2007 & 2008 & 2009 & 2010 & 2011 & 2012 \\
\hline Ireland & 30.7 & 29.5 & 27.3 & 24.6 & 25.1 & 44.5 & 64.8 & 92.1 & 106.4 & 117.6 \\
\hline Greece & 97.4 & 98.6 & 100 & 106.1 & 107.4 & 112.9 & 129.7 & 148.3 & 170.3 & 156.9 \\
\hline Spain & 48.8 & 46.3 & 43.2 & 39.7 & 36.3 & 40.2 & 53.9 & 61.5 & 69.3 & 84.2 \\
\hline Italy & 104.1 & 103.7 & 105.7 & 106.3 & 103.3 & 106.1 & 116.4 & 119.3 & 120.8 & 127 \\
\hline Portugal & 59.4 & 61.9 & 67.7 & 69.4 & 68.4 & 71.7 & 83.7 & 94 & 108.3 & 123.6 \\
\hline \multicolumn{8}{|c|}{ CREDITORS } \\
\hline Germany & 64.4 & 66.2 & 68.5 & 68 & 65.2 & 66.8 & 74.5 & 82.4 & 80.4 & 81.9 \\
\hline France & 62.9 & 64.9 & 66.4 & 63.7 & 64.2 & 68.2 & 79.2 & 82.4 & 85.8 & 90.2 \\
\hline Netherlands & 52 & 52.4 & 51.8 & 47.4 & 45.3 & 58.5 & 60.8 & 63.1 & 65.5 & 71.2 \\
\hline
\end{tabular}

Source: Eurostat statistics database

Current account deficit and trade deficit combined with negative net investment position leads to conclude that periphery countries financed its imbalances by borrowings in abroad. Let us look into Net investment position per country presented in the following table (Table 5).

Table 5 Net Investment Position in Percentage of GDP

\begin{tabular}{|l|c|c|c|c|c|c|c|c|c|c|}
\hline \multicolumn{10}{|c|}{ PIIGS } \\
\hline & 2003 & 2004 & 2005 & 2006 & 2007 & 2008 & 2009 & 2010 & 2011 & 2012 \\
\hline Ireland & -20 & -17.9 & -24.5 & -5.3 & -19.5 & -75.6 & -92.4 & -88 & -93.9 & -108.2 \\
\hline Greece & -58.9 & -67 & -77.3 & -85.4 & -96.1 & -76.8 & -89.6 & -98.4 & -86.1 & -114.5 \\
\hline Spain & -45.2 & -51.9 & -55.6 & -65.8 & -78.1 & -79.3 & -93.7 & -88.8 & -90.6 & -91.4 \\
\hline Italy & -13.6 & -15.8 & -16.8 & -22.2 & -24.5 & -24.1 & -25.3 & -23.9 & -20.7 & -24.8 \\
\hline Portugal & -57.5 & -64.1 & -66.9 & -78.8 & -87.9 & -96.2 & -110.3 & -107.2 & -104.9 & -116.7 \\
\hline \multicolumn{8}{|c|}{ CREDITORS } \\
\hline Germany & 6.6 & 10.7 & 21 & 27.9 & 26.5 & 25.4 & 33.8 & 34.9 & 32.6 & 40.4 \\
\hline France & -4.2 & -4.7 & 1.1 & 1.1 & -1.5 & -12.9 & -9.4 & -12.5 & -18.8 & -21.1 \\
\hline Netherlands & -1.7 & 3.7 & -2.6 & 3.2 & -6 & 4.2 & 16.7 & 24.5 & 36.4 & 54.1 \\
\hline
\end{tabular}

Source: Eurostat statistics database

The data presented indicate that external borrowings had been used to finance current and trade account deficits before the crisis. Greek net investment position in percentage of GDP worsened from 58.9 in 2003 to 96.1 in 2007. 
According to Todorovic and Bogdanovic (2011), the crisis in Greece occurred as a result of the large borrowing in international capital markets to finance the budget deficit and current account deficits (Todorovic and Bogdanovic 2011).

As in the case of Greece, the similar conclusions can be drawn from Spain and Portugal whose net investment position in percentage to GDP passed from 45.2 and 57.5 in 2003 to 78.1 and 87.9 in 2007. Italy also recorded continuous increment of negative net investment position during the observed period while Ireland has visible oscillations in net investment position, but having in mind that this country has a trade surplus, there we can draw the other conclusions.

As Whelan (2013) explain, Ireland was seen by many as the top of the European class in its economic achievements with a long period of high rates of economic growth and low unemployment that combined with budget surpluses. However, the subsequent crash - involving a housing market collapse, soaring unemployment and a full scale-banking crisis - proved too difficult for the Irish government to manage on its own (Whelan 2013).

\section{Net Investment Position of Creditor Countries - Breakdown}

We showed that the net investment position of creditor countries has an increasing trend before the crisis in parallel with the current account deficit and budget deficit growth in periphery countries (PIIGS). It is not necessarily true that Germany, for example, has financed the current account balance of Greece. It could be that Greece has financed its current account deficit by borrowing outside of the EU. Meanwhile, we assume that creditor countries have been much more involved in capital flows than in real flows through the EU. In order to investigate that possibility, we present a breakdown of Net investment position of creditor countries in this part. In a later stage, we will show a total exposure of creditor countries toward PIIGS.

Table 6 International Investment Position of Germany - Assets Side

\begin{tabular}{|l|c|c|c|c|c|c|c|c|c|c|}
\hline \multicolumn{1}{|c|}{ billion EUR } & $\mathbf{2 0 0 3}$ & $\mathbf{2 0 0 4}$ & $\mathbf{2 0 0 5}$ & $\mathbf{2 0 0 6}$ & $\mathbf{2 0 0 7}$ & $\mathbf{2 0 0 8}$ & $\mathbf{2 0 0 9}$ & $\mathbf{2 0 1 0}$ & $\mathbf{2 0 1 1}$ & $\mathbf{2 0 1 2}$ \\
\hline Direct investment & 570.6 & 595.1 & 678.3 & 768.6 & 848.3 & 898 & 943.4 & 1022.1 & 1048.1 & 1108 \\
\hline Portfolio investment & 1097.8 & 1243.1 & 1566.1 & 1719.4 & 1791.3 & 1541.7 & 1733.4 & 1888 & 1785.6 & 2028.3 \\
\hline Loans, currencies and deposits & 1286.5 & 1405.9 & 1549.8 & 1794.8 & 2012.1 & 2061.3 & 1890.6 & 1920.9 & 2009.8 & 1888.8 \\
\hline Trade credits & 81.1 & 82.1 & 90.7 & 106.5 & 112.4 & 111.8 & 102 & 111.7 & 120 & 118.1 \\
\hline Financial derivatives & & & & & & & & 784.2 & 916 & 847 \\
\hline $\begin{array}{l}\text { Participating interest in internationation } \\
\text { organisations }\end{array}$ & 15.3 & 15.5 & 16.7 & 16.6 & 16.5 & 2.2 & 2.2 & 2.1 & 2.2 & 11 \\
\hline Other assets & 29.8 & 32.4 & 36 & 40.4 & 44.3 & 48.7 & 51.6 & 54.7 & 58.2 & 60.2 \\
\hline Bundesbank & 76.7 & 71.3 & 86.2 & 104.4 & 179.5 & 230.8 & 323.3 & 524.7 & 714.7 & 921 \\
\hline TOTAL & 3157.8 & 3445.4 & 4023.8 & 4550.7 & 5004.4 & 4894.5 & 5046.5 & 6308.4 & 6654.6 & 6982.4 \\
\hline
\end{tabular}

Source: Boundesbank statistics ${ }^{1}$

\footnotetext{
${ }^{1}$ http://www.bundesbank.de (2012) [Accessed 01/05/13]
} 
According to the above data, Germany's main international assets refer to loans, currencies and deposits as well as portfolio investments representing jointly more than $70 \%$ of the German holding in abroad during the observed period (Table 6). On the other side, direct investments represent less than 20\%. Let us look how much other members of the EU place FDI directly. The similar situation appears in France. Based on the data presented in the following table, direct investments in abroad represented less than $28 \%$ of total assets in abroad while portfolio investments and placements through loans, currencies and deposits represent almost 70\% of total France investments in abroad (Table 7).

Table 7 International Investment Position of France - Assets Side

\begin{tabular}{|c|c|c|c|c|c|c|c|c|c|c|}
\hline billion EUR & 2003 & 2004 & 2005 & 2006 & 2007 & 2008 & 2009 & 2010 & 2011 & 2012 \\
\hline Direct investment & 749.6 & 847.1 & 1044.6 & 1222.4 & 1219.2 & 911.0 & 1099.1 & 1135.9 & 985.3 & 1134.5 \\
\hline Portfolio investment & 1084.4 & 1285.3 & 1587.9 & 1851.0 & 2014.1 & 1857.4 & 2049.9 & 2078.0 & 1826.7 & 1947.9 \\
\hline Loans, currencies and deposits & 632.9 & 712.6 & 972.8 & 1079.6 & 1240.0 & 1188.6 & 1131.1 & 1289.6 & 1531.0 & 1454.1 \\
\hline Trade credits & 88.6 & 91.3 & 88.9 & 83.8 & 85.7 & 84.9 & 78.4 & 78.0 & 105.4 & 105.0 \\
\hline Other assets including financial derivatives & 93.1 & 116.9 & 124.5 & 159.2 & 241 & 234 & 273.5 & 868 & 1237 & 1301.6 \\
\hline Reserve assets & 56.0 & 56.8 & 63.0 & 74.6 & 78.6 & 74.0 & 92.4 & 124.5 & 133.1 & 139.9 \\
\hline TOTAL & 2704.5 & 3109.9 & 3881.8 & 4470.5 & 4878.6 & 4349.8 & 4724.3 & 5574.0 & 5818.5 & 6083.0 \\
\hline
\end{tabular}

Source: Banque de France statistics

The first impression is that creditor countries more invested in financial assets than through the FDIs. However, it is not necessarily true that most of capital investments from creditor countries were transferred to the PIIGS countries. This requires a look to creditors' exposure to the concrete PIIGS country.

According to Avdjiev et al. (2011), in the end of the third quarter of 2010, the total consolidated foreign exposures (on an ultimate risk basis) of BIS reporting banks to Greece, Ireland, Portugal, and Spain stood \$2,512 billion (Appendix 1). At \$1,756 billion, foreign claims were equal to approximately $70 \%$. The remaining $\$ 756$ billion was accounted for by other exposures - i.e. the positive market value of derivatives contracts, guarantees extended and credit commitments (Avdjiev et al. 2011).

\section{EU Intra-Regional Trade Imbalances}

Intra-regional trade between the member states of the European Union (EU) plays an important role representing more than $60 \%$ of total EU trade. Approximately $60 \%$ of the total intra-EU trade volume (in 2012) is concentrated in the following countries: Germany (21.5\%), France (11\%), Netherlands (10.7\%), Belgium (8.5\%), and Italy (7.3\%). The United Kingdom has also a significant portion in total volume of intra-EU trade (7.9\%) but having in mind that UK does not participate in the single currency union, it will be excluded from our further analysis. Since the creation of the EU and especially since the introduction of common currency, intra-regional trade within the EU has an 
increasing trend. According to theory, intra-regional trade tends to have an increscent trend during the period of economic prosperity and vice versa, it tends to decrease during the period of crisis and stagnation. This trend is usually driven by countries, which have the most significant single portion in total intraregional trade, and it was especially visible during the second half of 2008 and during whole 2009 as a result of the global economic crisis. As presented in the figure below, during the economic prosperity intra-EU trade tends to increase faster than trade with third countries, while during the economic slowdown intra-regional trade tends to drop faster than trade with countries outside EU (Figure 1).

Figure 1 EU's Total Trade Volume

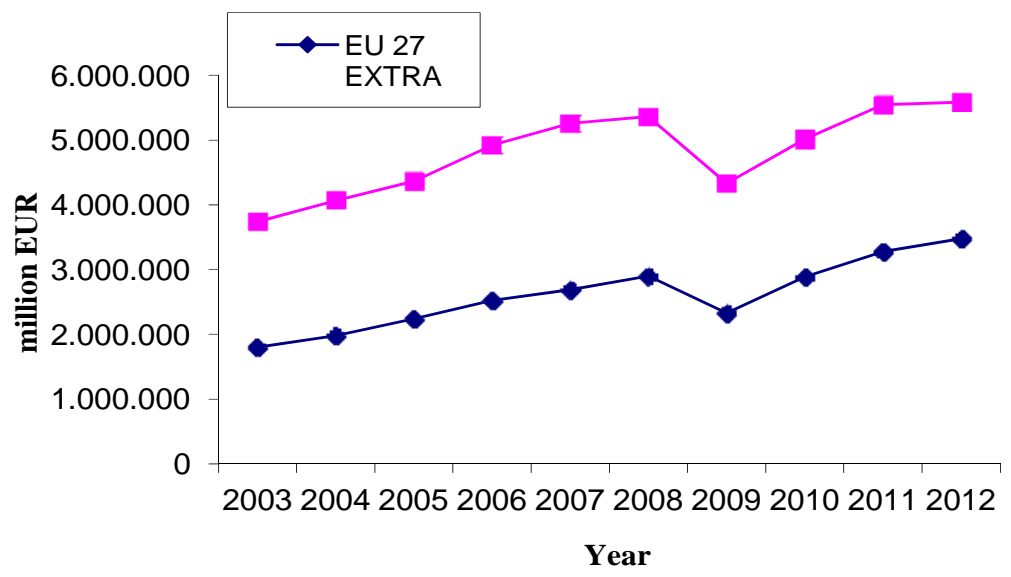

Source: Authors' calculations

The EU as a whole is the biggest trader in the world. However, trade performances within the EU are largely different between the member countries showing the existence of significant intra-European imbalances.

Regarding total trade balance, the continuous trade surpluses during the last decade had Germany, the Netherlands, and Ireland. The countries with smaller but continuous trade surplus are Sweden, Belgium, Denmark, and the Czech Republic (except for 2003 and 2004). On the other side, continuous trade deficit during the last decade is characteristic of France, Spain, and Greece. The countries with smaller but continuous trade deficit are Bulgaria (except for 2005), Portugal, Poland, Romania, Luxembourg, Austria, and Italy (except for 2012). Other countries have oscillating trend of trade balance during the observed period. However, in order to deeper investigate trade imbalances within the EU we need to split the trade balance between external trade balance and intra-regional trade balance. 
The countries that have continuous both trade surpluses are Germany, Denmark, and Ireland. Bearing in mind the low portion of Denmark trade in total EU trade, it is obvious that Germany is the leading trader in the EU. Germany's trade surplus came from both intra-regional trade and trade with partners outside the EU while the biggest portion of total trade surplus came from intra-EU trade. On the other side, Ireland total surplus is almost equally split between trade with third countries and trade with European partners. The countries whose total trade surpluses primarily come from intra-regional trade are the Netherlands, Belgium, and the Czech Republic. These countries record a negative trade balance in trade with countries outside the EU.

Regarding continuous deficit during the last decade, the countries recording both intra-EU trade deficit and external trade deficit are France, Greece, Spain, Portugal, and Cyprus. Let us look at the figure below representing the ten-year trend of intra-EU trade balance of PIIGS countries (Figure 2):

Figure 2 PIIGS Intra Trade Balance.

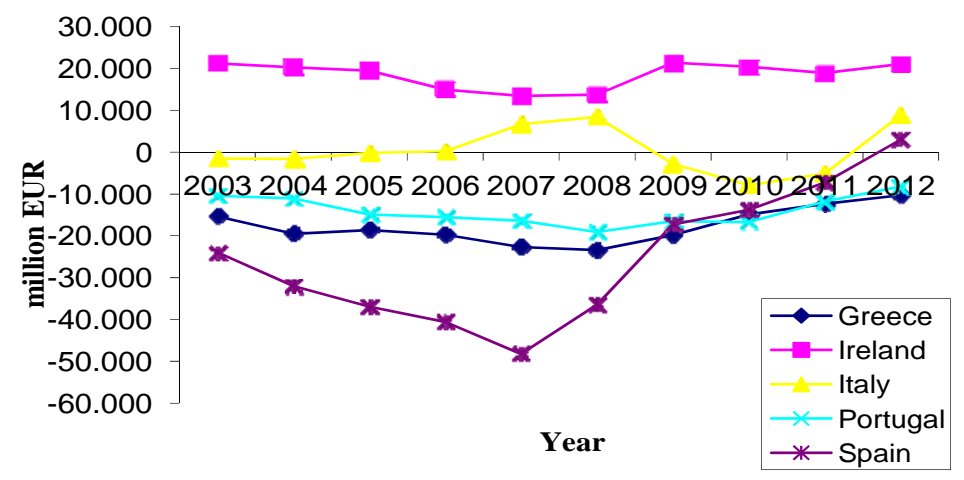

Source: Authors' calculations

In the years before the crisis, i.e. Greece, Portugal and especially Spain increased its intra-EU trade deficit while Italy had a positive trend of intraregional trade balance (decrease of deficit) achieving the intra-EU trade surplus in 2007.

As the data shows, Greece has been recording a gradual growth of deficit in trade with countries outside EU until 2007 (Figure 3). With the simultaneous increase of deficit in trade with European partners, Greece cumulated a total trade deficit. The same situation happened in Spain. Both, intra-regional trade deficit and external trade deficit had a permanent growth until 2007. Portugal followed the same trend but with less or more stable trend of trade balance with non-EU countries. Italy followed the same trend as Greece recording deficit from both activities, trade with European partners and trade with external partners. While Italy had had a positive trend of intra-EU trade balance in the 
years before the crisis, external trade balance was negative. Let us look now the figure below representing intra-EU trade balances of so-called creditor countries (Figure 4).

Figure 3 PIIGS Extra Trade Balance.

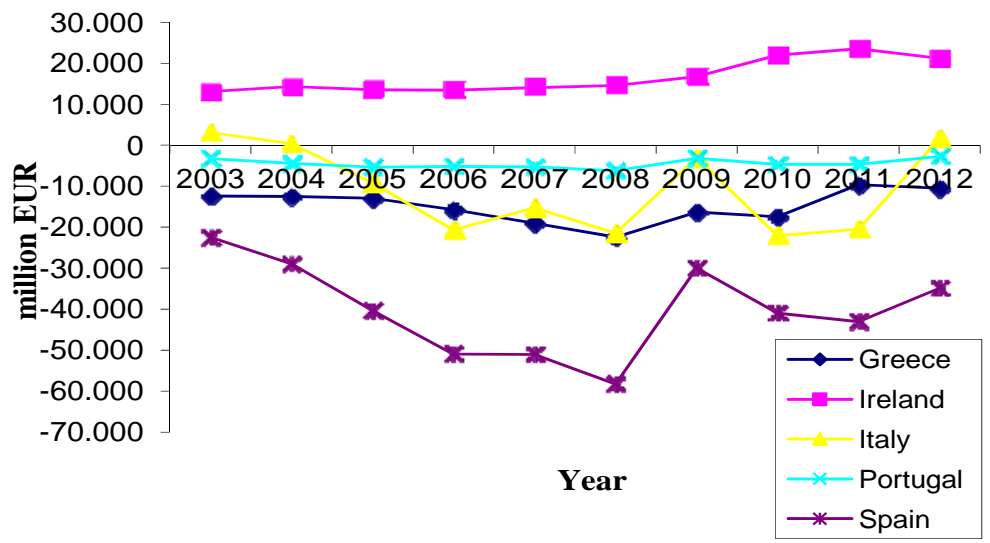

Source: Authors' calculations based on Eurostat statistics

In the years before the crisis, Germany and Netherlands recorded a growth of intra-regional trade surplus while France consciously increased trade deficit from trade with EU members.

Figure 4 Creditors’ Intra Trade Balance.

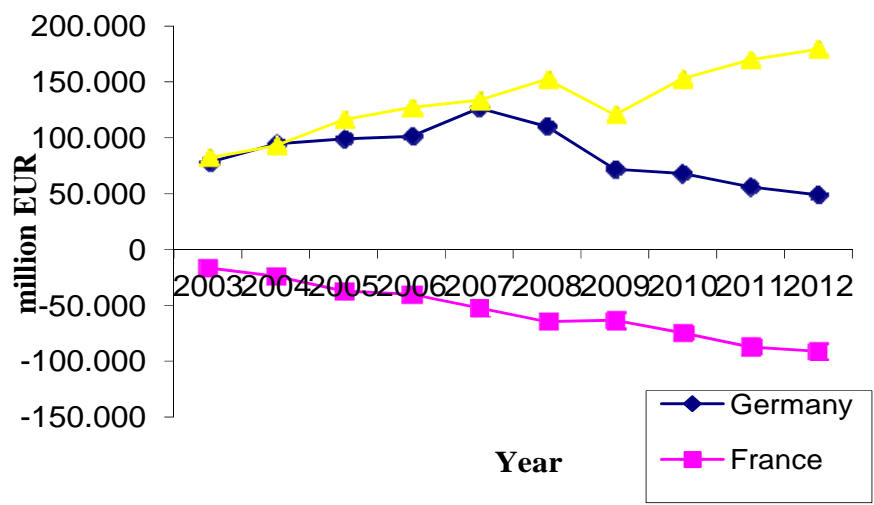

Source: Authors' calculations based on Eurostat statistics

According to the above data, Germany's surplus from trade with non-EU countries was relatively stable and even increased during the years before the crises (Figure 5). France had a negative trend of external trade surplus during the observed period. With a cumulated deficit from intra-EU trade, France total trade 
deficit increased by 2007. During the years before the crisis, the Netherlands recorded an increase of trade deficit in trade with countries out of the EU.

Figure 5 Creditors Extra Trade Balance.

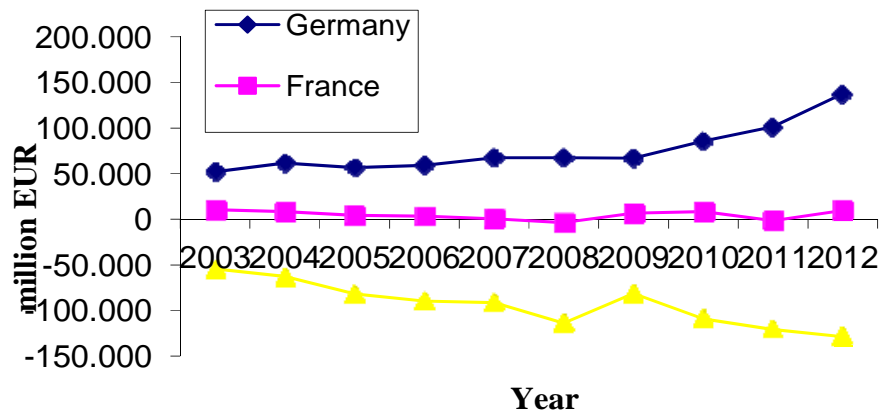

Source: Authors' calculations based on Eurostat statistics

To summarise, Greece, Spain and Portugal increased both, deficit in intraregional trade and deficit from trade with non-EU countries until 2007. With the constant increase of negative net investment position, it is obvious that the total trade deficit was financed by external borrowings. Italy had a positive trend of intra-EU trade balance, but it significantly worsened its external trade position.

The interesting trend regarding intra-regional trade was evidenced in the case of the Netherlands and France. France recorded cumulative negative trend in both, intra-EU trade and trade with countries outside the EU showing that country evidently lost its competitiveness. On the other side, the Netherlands had a positive trend of intra-EU trade balance with the simultaneous negative trend of performance in trading activity with countries outside the EU.

\section{Why Intra-Regional Trade is Falling Sharply When the Crisis Occurs?}

We would like to point out one very important trend regarding intra-EU trade that occurred with global economic crisis in 2007. When the crisis occurred, total intra-regional trade volume dropped stronger than volume of EU trade with third countries. What triggered such a trend? We put attention to five biggest traders in the EU whose trend of intra-EU trade volumes generally explains a trend of total intra-regional trade volume within the Eurozone: Germany, France, Netherlands, Italy and Spain.

Approximately $65 \%$ of Germany trade surplus came from intra-EU trade. This surplus was seen as a trade deficit in the Germany trade partners. In the 
words of Guerrieri (2012), surplus and deficit euro member countries are mirror images of each other.

To remind, Germany biggest trading partners within the EU are France, UK, Netherlands, Austria, Italy, Belgium, Poland, the Czech Republic, and Spain. Looking only at 2008, the Germany trade surplus with non-EU countries was almost the same (var. $-0.1 \%$ ) compared to the previous year while trade surplus with EU countries dropped by $13.2 \%$, mostly due to export decrease! The year 2009 showed an even stronger decrease of Germany intra-EU trade surplus: total trade surplus dropped by $21.8 \%$ mostly due to $34.7 \%$ decrease of intraregional trade surplus while a drop of external trade surplus was only $0.8 \%$. The year 2010, which is considered as a recovery year for the global economy and international trade, brought to Germany $10.9 \%$ of the trade surplus increase. However, this surplus was mainly driven by trade with non-EU countries (var. + 28.2\%), notably with China and other emerging markets while trade surplus with EU countries continued to decrease (var. -5.3\%). The same trend continued in 2011 and 2012. It is important to mention that intra-EU trade surplus portion in total Germany trade surplus dropped from 65\% in 2007 to $26 \%$ in 2012 !

The continuous drop of German surplus in trade with European partners after the crises directly reflects that Europe seriously retarded in recovery and even entered into its own crises.

Contrary to Germany, France has recorded continuous trade deficit during the last ten years and the most contribution significant in building of trade deficit has deficit in trade with EU countries. Even France recorded surplus from trade with non-EU countries in 2009, 2010 and even in 2012, permanent increase of intra-EU trade deficit since 2007 makes France to be trade deficit country. The Netherlands has had traditionally trade surplus country recording continuous trade surpluses during the last decade. However, the Netherlands trade surplus came from trade with European partners while trading activity out of the EU brings the trade deficit in this country.

Italy is the country with trade deficit, which mostly came from trade with third countries. Until 2008, Italy had been recording a surplus in trade with its European partners. From 2008 to 2012, Italy trade balance with EU countries was negative.

Spain is the one of the biggest deficit countries within the EU recording trade deficit in both trade with EU partners and trade with third countries. Contrary to Italy, intra-EU trade deficit decreased from 2008 to 2012.

Based on the data presented, we can conclude that only Germany kept its continuous trade surplus in trading activity out of the EU. 
According to Keynes General Theory, country's competitiveness is driven by costs related to productivity growth and the exchange rate. One may conclude that the introduction of euro mostly served to boosting of German trade surplus, but there exists some additional explanation. If Germany had boosted its external trade surplus due to common currency, how it was able to maintain it? Why the countries with continuous intra-EU trade deficit are not being able to compensate it by trade surplus in trade outside the EU? There were some discussions that periphery countries losing external competitiveness because the appreciation of the euro.

In the case of intra-regional trade, if the countries share the common currency then the only measure of competitiveness can be the productivity. Therefore, even one part of German competitiveness can be due to exchange rates, it is undisputed that German disposes of real competitiveness, which is even more visible inside of the EU through the intra-regional trade. The answers have to lie in a strong imbalance in competitiveness between the EU members.

Bibow (2012) concluded that Germany had a significant role in building of intra-European imbalances. He reminds us that the vital importance of relative national wage and productivity trends inside a monetary union can be more easily understood in terms of Mundell's (1961) seminal contribution to "optimum currency area" (OCA) theory, focusing on "asymmetric shocks" and how either market mechanisms and/or policy responses might help to re-balance economies (Bibow (2012). Ironically, it was Germany, of all countries, that came to depart from its own historical stability norm under the Maastricht regime with potentially fatal consequences for the euro (Bibow 2012).

Let us look at the relevant data for the explanation of competitiveness labour costs and inflation rate. It indicated that nominal unit labour costs diverge between the observed countries (Figure 6).

Figure 6 Nominal Unit Labour Costs.

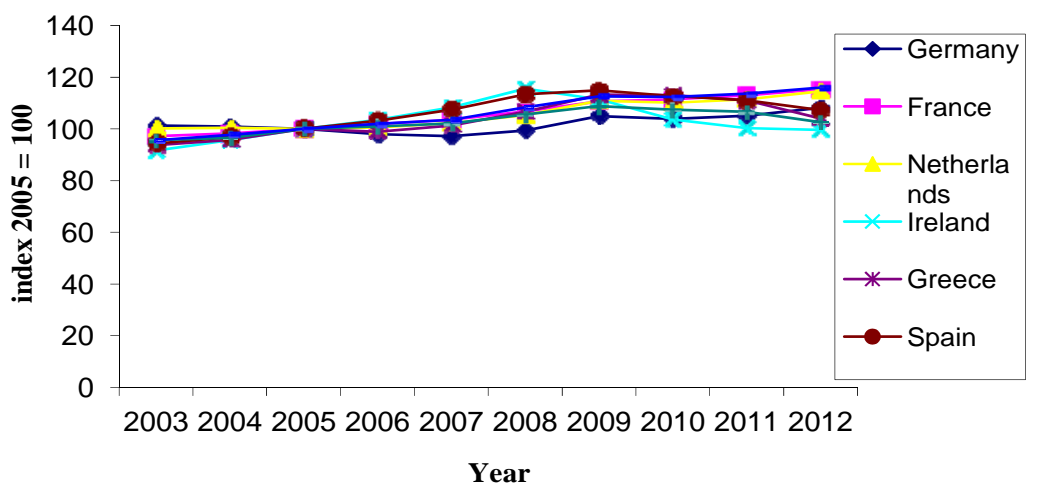

Source: Authors' calculations 
Figure 7 HICP - Inflation Rate

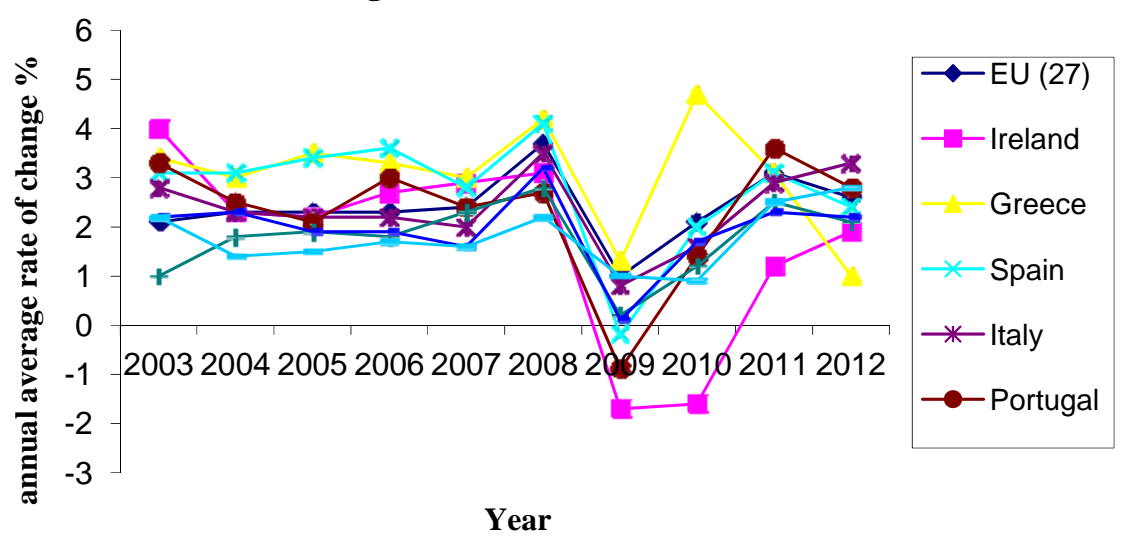

Source: Authors' calculations

The above data shows that Germany has low inflation but still much closer to the targeted percentage compared to the other countries (Figure 7). The Netherlands recorded even lower inflation while France was also close to these numbers. If we look at PIIGS countries, they also go away from the target but in a much higher percentage and in an opposite direction. The unit labour cost divergences can be explained by two factors: firstly, many Eurozone members have recorded wage increases that exceeded productivity gains. On the other side, decrease of unit labour costs in Germany can be partially explained by Germany's so-called Agenda 2010 reforms. Coordination of government, business leaders, and labour unions lead to consensus regarding the wages. The combination of lower wages with reducing of safety for the unemployed has a positive impact on acceptance of less paid jobs. Additionally, one part of the production was outsourced, which contributed to maintain the trend of low wages.

Therefore, the German export model often called as a model of success was not intended against the European partners but included two factors that were not so favourable from economic and regional integration point of view: lower domestic demand and investment mostly oriented toward safe haven.

As Blankart (2012) explaines, between inflation regime and stability regime, Germany opted for the second one. After the currency union had been established, the Stability and Grow Pact was not able to affect much and the rules softened permitting to Mediterranean countries to maintain inflation regime, and instead of devaluing now and then and thereby making their economies competitive, they accumulated ever-higher public debts, which was not sustainable (Blankart 2012). 


\section{Target 2 - More Evidences of European Imbalances}

According to ECB definition, TARGET-2 is the real-time gross settlement (RTGS) system owned and operated by the Euro system. TARGET stands for Trans-European Automated Real-time Gross settlement Express Transfer system.

As Jobst et al. (2012) explains the TARGET-2 transaction involves two banks and/or two central banks. Every commercial bank is assigned to one of the central banks of the Euro-system (18 altogether, including the ECB), which jointly use TARGET-2. Every transfer of funds gives rise to TARGET-2 claims of the receiving bank and TARGET-2 liabilities of the sending bank. Since the transfer takes place between two central bank accounts, the sending bank must have sufficient balances in its current account with its home central bank or take out Intraday credit, in the form of an adequate collateralised overdraft, in line with the applicable guideline.

Sinn (2012) asserts that TARGET-2 "helped maintain and prolong structural current account deficits” of peripheral countries. Sinn (2012) indicates that imbalances within the EU have significantly increased showing a huge deficit in PIIGS countries while counterpart to this increase is visible in the sum of the accumulated balance of payments surpluses (Target claims) in Germany. He further explains that since crises begun the PIIGS countries became unable to borrow, they turned to national central banks who then issued new created money, then new created money flowing out to the rest of the Eurozone like privately borrowed money before the crisis, creating the net outflow of money measured in the Target or balance of payment statistics (Sinn 2012). Finally, Target credit that the periphery countries were able to draw out of the Eurosystem by forcing other euro countries, predominantly Germany; to provide this credit. (Sinn 2012). Sinn opened a serious public debate regarding TARGET-2 especially in Germany. We are not in accordance with neither Sinn conclusions nor its opponents. However, even we are sceptical with Sinn arguments that TARGET-2 is a source of additional imbalances within the EU; the fact that TARGET-2 surely reflects the imbalances within the EU is self-evident.

\section{Relation between the Debt and Banking Crisis}

According to some academics and analysts, the European debt crisis is interrelated with the banking crisis. The so-called twin crises have been studied a long time ago. Kaminski and Reinhart (1999) present one of the earlier works regarding twin crises (Mexican and Asian turmoil). The strong link between the banking crisis and sovereign default is well presented in the work of Reinhart and Rogoff (2010). According to mentioned authors, private debt surges are a recurring antecedent to banking crises, governments quite contribute to this stage of the borrowing boom. The authors further explained that banking crises 
often precede or accompany sovereign debt crisis (Reinhart and Rogoff 2010). Additionally, public borrowing accelerates markedly ahead of a sovereign debt crisis; governments often have "hidden debts" that far exceed the betterdocumented levels of external debt (Reinhart and Rogoff 2010).

Blundell-Wignall and Slovik (2011) identify European crisis as a twin crises of the banking crisis and sovereign debt crises. Bond spreads faced by Greece and Ireland, and to a lesser extent Portugal followed by Spain, have increased. Greece and Portugal, on the one hand, where the problems are primarily fiscal in nature; and Ireland and Spain, on the other, where banking problems related to the property boom and bust have been the key moving parts (BlundellWignall and Slovik 2011).

After publishing revised Greek budget deficit for 2009 and decrease in Greece credit rating, investors started to be very obsessed. Market reactors have punished Greece by pushing up the interest rates for additional borrowing. As the data shows, the yield on Greek bonds significantly raised which reflects a decrease of investors' confidence in the Greek economy (Figure 8).

Figure 8 Greek Bonds Yield - 10Y Maturity.

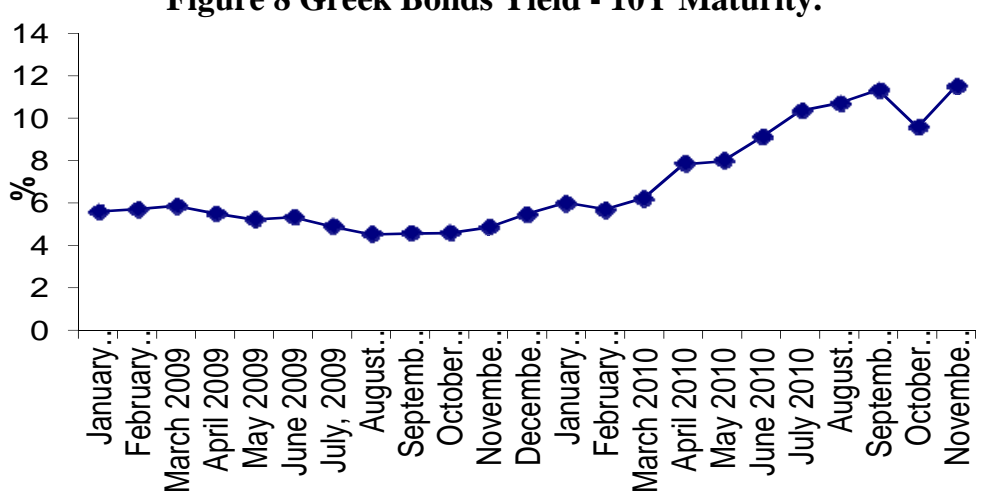

Source: Authors' calculations

It is important to mention here that Greek data about economic performance had been known even before but market reaction came much later. Why the market did not react earlier? Some authors blame the rating agencies claiming that they should react much earlier. On the other side, why someone continues to invest in government bonds even fundamental indicators show that the crisis is approaching?

In our view, there are several problems deserving to be addressed. Firstly, government bonds are still treated by international banking regulation (Basel) as a zero risk investment. As long as an asset brings the good yield with zero risk, profit oriented investor will diversify its portfolio in this direction. However, how much the rational investors use a fundamental analysis? Moreover, how 
much probability of default is properly used in sovereign risk measure? This can be a subject of some future research.

Aside from all mentioned questions, the most important problem in our view lies at the base of monetary union. If the European monetary union has one currency, and if the monetary policy is not anymore in the hands of National Central Banks, does the issuing of government bonds of each country still make sense then.

Mundell (2012), often called the godfather of the euro, points out that the euro area suffers from two great defects out of which the one is the fact that there are 17 banking systems in the euro area, and the other is that there are 17 nations with treasury bills and bonds. (opinion.financialpost.com 2012).

Contrary to Greece, Ireland experienced pure banking crisis which was intensified by global crisis in 2007. As we earlier presented, Ireland was the only country with a trade surplus in the years before the crisis. Irish positive economic environment during the previous period was attracting lots of capital flows. Membership in the EU and Eurozone additionally helped easier access to cross-border funding. The country has increased employment, activity, export, and living standard. However, growth was based on an inflation model meaning that inflation and wages had an increasing trend leading to drop of Ireland competitiveness. In the several years before the crisis, Ireland trade surplus had started to decrease. On the other side, the mortgage credits and investments in real estates had an increasing trend jointly with the consumption and other type of loans. With the global economic crisis in 2007, the housing market bubble jointly with asset prices drop led to the losses of the banking system and to the liquidity problem. The rescue of the banking system was too expensive therefore causing the increase of the public debt. Financial markets reacted once again by pushing interest rates up but the punishment of Ireland which was not as bad as in the case of Greece. Increase in interest rates was reflected in bond yield growth (Figure 9).

Figure 9. Irish bonds yield - 10Y maturity.

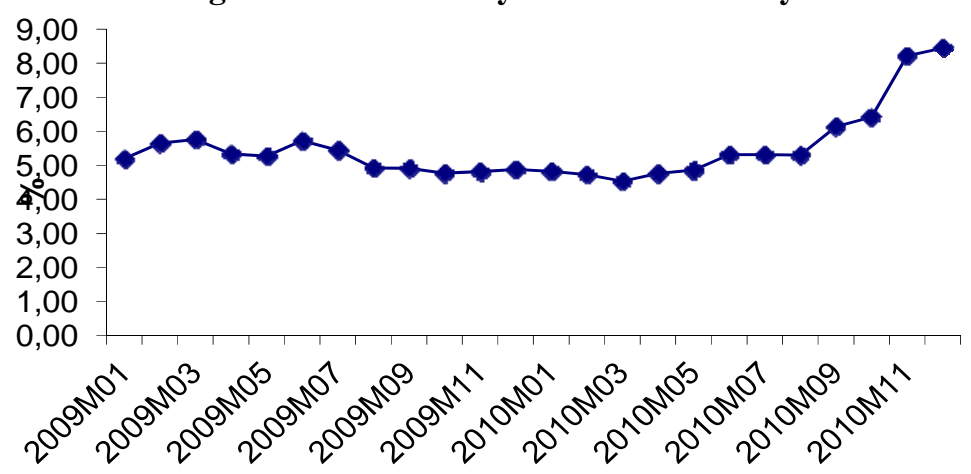

Source: Authors' calculations based on Eurostat statistics 
According to previously presented BIS statistics, the biggest holders of Ireland debt in 2012 were the European countries. As in the case of Greece and Ireland, financial markets felt the coming crisis in Spain in Portugal and reacted in the same manner. Consequently, the interest rates on government bonds of Portugal, Spain, and Italy started to increase making additional borrowings much more expensive.

Blundell-Wignall and Slovik (2011) in their work Market Perspective on the European Sovereign Debt and Banking Crisis explain that prior to the financial crisis, peripheral European spreads were very narrow, but as growth fell and budget deficits ballooned, the risk of restructuring came into play and had a causal influence on the issue of liquidity. When economic performance deteriorates in this manner, market participants assign their own scenarios for default. (Blundell-Wignall and Slovik 2011). The wide spread of banking crises is here presented in the sense of its interconnection with a debt crisis. The two crises are interlinked in different ways. Even banking crisis usually precedes to the sovereign debt crisis the impact can be also inverse. Although the banking system in one country can be relatively healthy, the sovereign debt crisis will provoke a negative impact. Even there is strong evidence that economic fundamentals lie at the base of EU crisis, it also deserves to be investigated in terms of market panic contribution to the wide spreading of the crisis. This could be a subject of some future research.

\section{How the Common Currency Contributed to the Eurozone Crisis?}

Introduction of euro has been promoted as a key driver of financial and economic integration within the European Union. The benefits of common currency have been widely treated in the literature, but once Eurozone crisis occurred, common currency become reevaluated in terms of its defects. There are several important points that deserve to be mentioned regarding euro contribution to the Eurozone crisis.

Introduction of euro directly eliminated foreign currency risk, but has also diminished transaction costs, which are seen as a positive impact on capital and trade flows. Indirectly, introduction of common currency contributed to decrease of credit risk based on economic fundamentals due to investors' positive perception regarding membership in Eurozone. Stronger financials integration leaded to convergence of asset prices and decrease of interest rates. This further led to enhancement of cross-border capital flows and greater borrowings by the countries with low credit worthiness. Membership in monetary union therefore assured an easy access to cheap loans for the countries that have had a weaker macroeconomic indicators and low repayment capacity. Finally, spending cheap funds on consumption necessarily lead to the 
state of over borrowing and bankruptcy. On the other side, additional inflows of foreign capital has additional pressure on real wages leading to higher inflation, worsening the current account and lowering the competitiveness.

The specificity of Eurozone crisis is that both, creditor and borrower countries are concentrated within the Eurozone which makes this region vulnerable to the shocks and subject to stronger contagion effects.

An introduction of euro had a positive impact on integration of European countries, but strong integration required a high level of supervision at common and national level. Even though the euro per se cannot be viewed as the only source of Eurozone crisis, there is strong evidence that during the time the advantages of the common currency have been converted into the weaknesses primarily due to underestimated risk related to economic fundamentals, as well as to insufficient supervision at national and common level.

\section{Conclusions}

The crises has affected the European Union since late 2009 containing the combination of sovereign debt crisis, a banking crisis, and balance of payment crisis. Multiplied crises threaten not only growth and competitiveness but also the common currency. The European officials recognised that the best way to fight the crisis is to achieve agreement and unity, which had resulted in decision to rescue the countries affected by the crisis.

Causes of the crises are different between the countries. The crisis in Greece was primarily due to permanent financing of current account deficit and budget deficit by external borrowings. Long period before the crisis, Greece cumulated not only current account deficit and trade deficit but also external borrowings and poor economic performances. Beside account deficit of 13.6\% of GDP in 2009 , trade deficit was also high and accounted for $18.6 \%$, as well as the budget deficit, which achieved $15.6 \%$. In the same year, Greek negative net investment position was $89.6 \%$ while gross government debt increased up to $129.7 \%$ of GDP. Greece seriously violated all European rules regarding economic indicators. Country rating has been downgraded by rating agencies and financial markets which expresses a serious loss of confidence in the Greek economy, which resulted in higher interest rates for additional borrowings. The yield on Greek 10-year maturity bonds increased from $5.49 \%$ in December 2009 to 12.1\% in December 2010. Having in mind that European banks own the majority of Greek sovereign debt, the concerns for banking system solvency in Europe rose especially during 2010. These concerns led European leaders to resort to financial support measures through the European Financial Stability Facility and European Stability Mechanism. At the same time, the governments focused on austerity measures. 
On the other side, the serious banking crisis has shaken Ireland. Banking crisis in this country came as a result of a credit crash in the housing market and fall in asset prices although Ireland had a favourable economic environment in previous years. While overrated current account deficit combined with high public deficit caused the Greek crisis, the debt crisis in Ireland appeared because of the rescue of the insolvent banking sector. Support to the banking sector had a negative impact on Ireland public debt that passed with $30.8 \%$ of GDP in 2010 while in 2007 its level was $0.1 \%$.

When it became obvious that Greece and Ireland entered into debt crisis, the markets immediately started to examine Portugal, Spain, and Italy having in mind that those countries also had unfavourable indicators. Portugal recorded $9.7 \%$ of budget deficits in 2010, Spain 9.8\% while Italy was more favourable with $4.5 \%$. However, after Greece, Italy was the second country with highest gross government debt $119.3 \%$ of GDP.

In this paper, we have analysed a large set of data from two groups of EU countries: periphery countries and creditor countries. Using the most relevant information and statistics for our analysis we came to following conclusions.

First, the European crisis seems to best correspond to the twin crises theories. On the one side, sovereign debt crisis was the result of balance of payment problems in several countries. On the other side, sovereign debt crisis was interconnected with typical banking crisis.

Second, Eurozone suffered from different imbalances between the member countries. Having in mind that interconnection between the Member States is best recognised in trade and capital flows, we find that creditor countries were much more involved in capital activity than in trade activity with periphery countries. To support this conclusion, we remind that biggest holders of periphery countries' debt were actually European creditor countries. Further, creditor countries have much more invested in financial assets than through foreign direct investments in PIIGS.

Third, intra-imbalances within the European Union have as the cause a misalignment of internal real exchange. Periphery countries, which based their economies in previous years on inflation model (increasing trend of wages, which is not based on productivity increase), lost their competitiveness. This is supported by the fact that unit labour costs seriously differ between the countries as well as the inflation rate and productivity.

Fourth, the European Union before the crisis did not assure an optimal currency area neither by prevention that national wages' trend becomes a source of shocks nor by ensuring sufficient mobility to serve as an adjustment measure when internal exchange rate adjustment is impossible. Here, we refer to Mundell's (1961) brilliant contribution to the theory of Optimum Currency Area. 
Fifth, even though the introduction of the common currency has a positive impact on financial and economic integration within the Eurozone, however, some of euro's positive effects converted into the negative ones during the time. Here, we primarily refer to the fact that membership in the Eurozone has an impact on underestimation of credit risk by investors regarding the borrowing to the countries having a weak economic performance and credit worthiness. Therefore, the common currency itself partially contributed to the crises.

It is important to explain that imbalances regarding trade should exist and will exist within the European Union regarding intra-EU trade because the surplus of one country has to be reflected in deficit of the other country. However, if the country continuously combines intra-regional trade deficit with deficit in trade with non-EU countries, that means that the general competitiveness of that country is seriously disrupted. Decreasing competitiveness of member countries can jeopardise the competitiveness of the European Union as a whole. It is not recommended here that periphery countries should resolve their own problems on their own having in mind their insufficient capacity for that, as well as the fact that their scope of competences is limited because monetary policy is out of their hands.

We suggest that dealing with crisis should be well coordinated between the member countries. While current European austerity is criticised by the opponents, some of austerity supporters find the austerity as the only meaningful measure on a short term. In our view, the most important fact is that now it is obvious that there is no more dilemma/trilemma. Europeans learned how much euro and the Union is important for them. European officials are now oriented towards monitoring and correction of macroeconomic imbalances under the framework of the Macroeconomic Imbalances Procedures (MIP). This demonstrates readiness of both deficit and surplus countries to work symmetrically on imbalances.

We stress the Mundell's (2012) optimism claiming that the euro is here to stay by being the glue that keeps the core of Europe together. Never before has there been a currency union that covers so large a share of the world economy and that has grown so successfully and so rapidly within the space of a decade and a half, so if the euro is a problem that is because the euro has been too strong, not too weak (www.bloomberg.com 2012).

\section{Acknowledgement}

The paper/article was accepted and presented at the EACES Workshop "Competitiveness of Firms, Industries, and Countries - Cause and Solution of European Crises" during 20th -21st September 2013, on the Faculty of Economics in Belgrade, Serbia. 


\section{References}

Avdjiev, S., C. Upper, and N.Vause (2011) "Highlights of the BIS international statistics", BIS Quarterly Review, March 2011.

Bibow, J. (2012) "The Euro Debt Crisis and Germany’s Euro Trilemma", Levy Economics Institute of Bard College, Working Papers, No. 721, 2012.

Blundell-Wignall, A. and P. Slovik (2011) "A Market Perspective on the European Sovereign Debt and Banking Crisis", OECD Journal: Financial market trends, 2: 9-36.

De Grauwe, P. (2011) "Crisis in the Eurozone and how to deal it", Working paper, No. 204, Centre for European Policy Studies, February 2010.

De Grauwe, P. (2012) "In search of the symmetry in Eurozone", CEPS Working Papers, No. 6901, Centre for European Policy Studies, May 2012.

ECB, J. (2013), "Intra-euro area trade linkages and external adjustment", ECB Monthly bulletin, 1: 59-74.

Featherstone, K. (2011) "The Greek Sovereign Debt Crisis and EMU: A Falling State in a Skewed Regime", Journal of Common Market Studies, 49 (2): 193-217.

Guerrieri, P. (2012) "Intra-European Imbalances: the Need for a Positive-sum-game Approach", IE BP Working Paper, No. 2012/03, The Royal Institute of International Affairs, Chatham House, December 2012.

Jobst, C., M. Handig, and R. Holzfeind (2012) "Understanding TARGET 2: The Eurosystem's Euro Payment System from an Economic and Balance Sheet Perspective", OeNB Monetary Policy \& the Economy, 12 (1): 81-91.

Kaminski, G. L., and C. M. Reinhart (1999) "The twin crisis: The causing of banking and Balance of Payment Problems", The American Economic Review, 89 (3): 473-500.

Mongelli, F. P. (2013) "The mutating euro area crisis: is the balance between" sceptics" and" advocates" shifting?", Working paper, No. 144, Occasional Paper Series, European Central Bank, February 2013.

Mundell, R. A. (1961) "A Theory of Optimum Currency Areas", The American Economic Review, 51 (4): 657-665.

Mundell R. A. (2012) "Euro is here to stay", Financial Post. Available at http:/opinion.financialpost.com/2012/06/08/robert-mundell-euro-is-here-to-stay/. Accessed 08/05/13

Mundell R. A. (2012), "The euro will survive the economic upheaval in Europe and defy critics", Financial Post. Available at http://www.bloomberg.com/news/2012-0609/nobel-winner-mundell-sees-euro-survival-financial-post-reports.html. Accessed 08/05/13

Muyer, T. (2011) "Euroland's hidden balance of payment crisis", Deutsche Bank Research, Report on European integration, EU Monitor 88, October 2011.

Rane, L. P. (2012) "The European sovereign debt crisis", Journal of Economic Perspectives, 26: 49-68.

Reinhart, C. M., and K. S. Rogoff (2010) "From Financial Crash to Debt Crisis", Working Paper Series, No. w15795, National Bureau of Economic Research, March 2010.

Sinn, H. W. (2012) "The European Balance of Payment Crisis: An introduction", in CESifo Forum (eds.), CESifo Forum (Vol. 13, No. Special Issue, January 2012), Ifo Institute for Economic Research at the University of Munich, pp. 03-10. 
Todorovic, M. and J. Bogdanovic (2011) "The European Union debt crisis and the Eurozone’s survival", Facta Universitatis, Series: Economics and Organisation, 8 (2): 165-180.

Whelan, K. (forthcoming) "Ireland's Economic Crisis: The Good, The Bad and the Ugly", Journal of Macroeconomics, Elsevier, In Press.

\section{MULTIPLIKATOR EVROPSKE KRIZE - OD JEDNE KRIZE KA DRUGOJ}

Apstrakt: S obzirom da je širenje krize u Evropskoj uniji (EU) uveliko počelo, istraživački radovi su do sada pružili različite definicije kao što su valutna kriza, kriza konkurentnosti, bankarska kriza, platno-bilansna kriza, pri čemu je najčešce susretan pojam kriza suverenog duga. U ovom radu, autori se slažu da se aktuelna evropska kriza prvenstveno ispoljila kao dužnička kriza, ali je u cilju uspostavljanja adekvatnih kriznih mera, neophodno dublje sagledati uzroke krize. U radu je identifikovan proces multiplikacije krize, pri čemu se zaključuje da je jedan oblik krize vodio ka drugom, ostajući pri stanovištu da je trenutna kriza u evrozoni u osnovi kombinacija platno-bilansne i bankarske krize. U cilju podrške hipotezi da je kriza suverenog duga duboko povezana sa krizom platnog bilansa, analizirali smo trgovinske tokove i tokove kapitala između evropskih zemalja. Potvrđeno je da su periferne zemlje pretežno finansirale deficit bilansa tekućih transakcija, spoljno-trgovinski deficit i budžetski deficit putem eksternog zaduživanja. Zemlje periferije su istovremeno uvećavale deficit i u trgovinskoj razmeni sa ostalim članicama EU i u trgovinskoj razmeni sa ostatkom sveta. Ključni uzrok unutrašnje neravnoteže u EU jeste različit nivo konkurentnosti njenih članica usled različitog nivoa produktivnosti. Kao drugo lice krize Evropske unije prepoznali smo bankarsku krizu. S tim u vezi, pokazali smo da su dužnička kriza i bankarska kriza međusobno povezane, ali da bankarska kriza obično prethodi dužničkoj krizi. Sa intenziviranjem međunarodnih tokova kapitala i naročito sa uvođenjem evra, intenzivirana je i finansijska integracija u evrozoni. Putem analize međunarodne investicione pozicije zemalja kreditora, konstatovano je da su ove zemlje u znatno većoj meri integrisane $\mathrm{u}$ evrozoni kroz finansijske tokove nego kroz realne ekonomske tokove. Osim toga, banke zemalja kreditora bile su među najvećim investitorima u obveznice perifernih zemalja poput Grčke, pa su sada suočene sa problemom solventnosti zbog pogoršanja bilansa. U zemljama kao što je Irska, spasavanje posrnulog bankarskog sistema dovelo je do povećanja javnog duga, što je kasnije rezultiralo u dužničkoj krizi. Na osnovu sprovedenih analiza, došlo se do zaključka da dužnička kriza u evrozoni u svojoj osnovi sadrži kombinaciju platno-bilansne i bankarske krize. Uzimajući u obzir da je u dosadašnjoj istoriji Evropske unije svaka kriza vodila ka daljem jačanju evropske integracije, možda ce i aktuelna kriza biti još jedan korak dalje u istom smeru.

Ključne reči: platno-bilansa kriza, bankarska kriza, konkurentnost, produktivnost, trgovina, dužnička kriza, zemlje periferije (PIIGS). 


\section{APPENDICES}

Appendix 1. Foreign Exposure

\begin{tabular}{|c|c|c|c|c|c|c|c|c|c|c|c|}
\hline \multicolumn{12}{|c|}{$\begin{array}{l}\text { Foreign exposures to Greece, Ireland, Portugal and Spain, by bank nationality } \\
\text { End-Q3 2010; in billions of US dollars }\end{array}$} \\
\hline \multirow[b]{2}{*}{$\begin{array}{l}\text { Exposures } \\
\text { to }\end{array}$} & \multirow[b]{2}{*}{ Type of exposure } & \multicolumn{10}{|c|}{ Bank nationality } \\
\hline & & $\mathrm{DE}$ & ES & FR & $\mathrm{IT}$ & OEA & GB & $\mathrm{JP}$ & US & ROW & Total \\
\hline \multirow{7}{*}{ Greece } & Public sector & & 0.6 & 19.8 & 2.6 & 15.7 & 3.2 & 0.5 & 1.8 & 1.5 & 72.0 \\
\hline & + Banks & 3.9 & 0.0 & 1.4 & 0.3 & 1.3 & 4.3 & 0.5 & 0.5 & 1.3 & 13.6 \\
\hline & + Non-bank private & 10.1 & 0.5 & 42.1 & 1.9 & 13.3 & 7.5 & 0.9 & 4.7 & 4.2 & 85.0 \\
\hline & + Unallocated sector & 0.0 & 0.0 & 0.0 & 0.0 & 0.0 & 0.0 & 0.0 & 0.0 & 0.1 & 0.1 \\
\hline & $=$ Foreign claims & 40.3 & 1.1 & 63.3 & 4.7 & 30.4 & 15.1 & 1.9 & 6.9 & 7.1 & 170.7 \\
\hline & + Other exposures & 29.2 & 0.4 & 28.7 & 1.7 & 3.1 & 5.3 & 0.1 & 36.2 & 2.4 & 107.2 \\
\hline & $=$ Total exposures & 69.4 & 1.5 & 92.0 & 6.5 & 33.5 & 20.4 & 2.0 & 43.1 & 9.5 & 277.9 \\
\hline \multirow{7}{*}{ Ireland } & Public sector & 3.4 & 0.3 & 6.6 & 0.8 & 3.7 & 6.6 & 1.5 & 1.5 & 0.7 & 25.1 \\
\hline & + Banks & 57.8 & 3.3 & 16.8 & 3.3 & 7.3 & 37.4 & 1.8 & 17.9 & 10.6 & 156.3 \\
\hline & + Non-bank private & 92.8 & 9.4 & 21.2 & 10.9 & 47.4 & 116.1 & 17.7 & 40.3 & 25.0 & 381.0 \\
\hline & + Unallocated sector & 0.0 & 0.0 & 0.0 & 0.3 & 0.2 & 0.0 & 0.0 & 0.0 & 0.8 & 1.3 \\
\hline & $=$ Foreign claims & 154.1 & 13.0 & 44.7 & 15.3 & 58.6 & 160.2 & 21.0 & 59.7 & 37.1 & 563.7 \\
\hline & + Other exposures & 54.3 & 4.5 & 33.4 & 9.1 & 8.6 & 64.4 & 1.5 & 54.2 & 20.2 & 250.1 \\
\hline & $=$ Total exposures & 208.3 & 17.5 & 78.1 & 24.4 & 67.2 & 224.6 & 22.5 & 113.9 & 57.3 & 813.7 \\
\hline \multirow{7}{*}{ Portugal } & Public sector & 8.4 & 8.8 & 16.1 & 0.9 & 7.8 & 2.6 & 1.3 & 1.6 & 1.5 & 49.0 \\
\hline & + Banks & 18.1 & 6.1 & 6.5 & 2.3 & 4.6 & 6.2 & 0.3 & 1.4 & 0.9 & 46.2 \\
\hline & + Non-bank private & 13.6 & 70.3 & 14.8 & 1.5 & 7.5 & 16.5 & 0.8 & 1.5 & 1.8 & 128.3 \\
\hline & + Unallocated sector & 0.0 & 0.0 & 0.0 & 0.0 & 0.0 & 0.0 & 0.0 & 0.0 & 0.0 & 0.0 \\
\hline & $=$ Foreign claims & 40.0 & 85.2 & 37.4 & 4.7 & 19.8 & 25.3 & 2.4 & 4.5 & 4.2 & 223.5 \\
\hline & + Other exposures & 8.5 & 23.4 & 8.1 & 3.2 & 2.1 & 8.5 & 0.4 & 42.6 & 1.5 & 98.3 \\
\hline & $=$ Total exposures & 48.5 & 108.6 & 45.6 & 7.9 & 22.0 & 33.7 & 2.8 & 47.1 & 5.8 & 321.8 \\
\hline \multirow{7}{*}{ Spain } & Public sector & 29.4 & . & 46.0 & 3.3 & 16.9 & 10.0 & 9.7 & 4.7 & 3.0 & 123.0 \\
\hline & + Banks & 85.8 & . & 55.8 & 9.0 & 49.1 & 34.0 & 4.5 & 20.6 & 11.0 & 269.7 \\
\hline & + Non-bank private & 85.7 & . & 81.3 & 16.2 & 98.5 & 72.4 & 10.2 & 26.3 & 14.7 & 405.3 \\
\hline & + Unallocated sector & 0.0 & . & 0.0 & 0.2 & 0.0 & 0.0 & 0.0 & 0.0 & 0.2 & 0.4 \\
\hline & $=$ Foreign claims & 200.9 & . & 183.1 & 28.7 & 164.6 & 116.3 & 24.4 & 51.6 & 28.9 & 798.5 \\
\hline & + Other exposures & 41.4 & & 41.6 & 13.1 & 15.0 & 36.1 & 4.8 & 136.0 & 12.4 & 300.3 \\
\hline & $=$ Total exposures & 242.4 & . & 224.7 & 41.8 & 179.6 & 152.4 & 29.2 & 187.5 & 41.31 & 098.8 \\
\hline \multicolumn{12}{|c|}{$\begin{array}{l}\mathrm{DE}=\text { Germany; } \mathrm{ES}=\text { Spain; FR = France; IT = Italy; OEA = other euro area; GB = United Kingdom; JP = Japan; US = United States; } \\
\text { ROW = rest of the world. }\end{array}$} \\
\hline \multicolumn{12}{|c|}{ Source: BIS consolidated banking statistics (ultimate risk basis). BIS Quarterly Review, March 2011} \\
\hline
\end{tabular}

